\title{
PENENTUAN RUMUS PERCEPATAN TANAH AKIBAT GEMPA BUMI DI KOTA MATARAM MENGGUNAKAN METODE EUCLIDEAN DISTANCE
}

\author{
Rian Mahendra Taruna ${ }^{1}$, Tio Azhar Prakoso Setiadi² \\ 1,2 Badan Meteorologi, Klimatologi, dan Geofisika \\ Kemayoran, Jakarta Pusat, Indonesia \\ e-mail: reemyan@gmail.com, tio.prakoso08@gmail.com
}

\begin{abstract}
Abstrak
Wilayah Lombok khususnya Kota Mataram dikategorikan sebagai kawasan dengan kerentanan tinggi terhadap gempabumi. Kota Mataram dikelilingi oleh beberapa zona sumber gempa termasuk subduksi dan back arc thrust. Peak Ground Acceleration (PGA) merupakan suatu parameter yang bisa menggambarkan dampak dari gempabumi. Pada penelitian ini kami menentukan persamaan terbaik untuk memperkirakan PGA di antara beberapa model yang ada. Metode yang digunakan untuk memilih persamaan adalah analisa residual dan Euclidean Disteance Ranking. Data yang digunakan terdiri atas nilai PGA dari accelerograph di Stasiun Geofisika Mataram (MAKE), katalog gempabumi di sekitar Mataram pada periode 2016 hingga 2018, dan kondisi situs di MAKE. Hasil penelitian menunjukkan bahwa beberapa persamaan memiliki hubungan yang baik dengan PGA hasil observasi di Kota Mataram yang penting untuk mitigasi gempabumi.
\end{abstract}

Kata kunci: Gempa bumi, PGA, Euclidean Distance

\begin{abstract}
Lombok region especially Mataram City is categorized as a high vulnerability area to the earthquake. Mataram city is surrounded by several earthquake source zones including subduction and back arch thrust. active seismic zone. Peak Ground Acceleration (PGA) is a parameter that can describe the impact of the earthquake. In this research, we determined the best equation to estimate PGA among several models. The method used to select equations was Residual Analysis and Euclidean Distance Ranking. Data set consisted of PGA from accelerograph in Stasiun Geofisika Mataram (MAKE), earthquake catalog around Mataram from 2016 until 2018, and site condition of MAKE. Results of this research show that some equation has good relation with observed $P G A$ in Mataram city which is important for earthquake mitigation.
\end{abstract}

Keywords : Earthquake, PGA, Euclidean Distance

\section{PENDAHULUAN}

Indonesia merupakan Negara

kepulauan yang terletak pada pertemuan tiga lempeng tektonik aktif dunia yaitu Lempeng Eurasia, Lempeng IndoAustralia dan Lempeng Pasifik yang bergerak satu sama lainnya. Kondisi ini menjadikan Indonesia sebagai daerah tektonik aktif dengan tingkat seismisitas atau kegempaan yang tinggi. Lokasi tektonik aktif di Indonesia secara sepintas sudah dapat dipastikan berada diperbatasan lempeng tektonik. Namun efeknya bisa dirasakan pada jarak tertentu tergantung pada peluruhan energi dan geologi setempat. Gempa bumi merupakan peristiwa pelepasan sejumlah energi pada batuan kerak bumi. Salah satu energi tersebut adalah energi gelombang yang disebut dengan gelombang seismik. Gelombang ini dipancarkan dari sumbernya dan menjalar kesegala arah, sehingga dapat dideteksi oleh sensor seismik. (Gunawan, 2005; Sari R, 2012).

Wilayah Lombok berada pada daerah seismik aktif yang dikelilingi beberapa sumber gempa. Di bagian utara 
Lombok terdapat sumber gempa back arc thrust (Taruna, Banyunegoro, 2018). Di selatan dan sekitar wilayah Lombok juga terdapat zona subduksi dan beberapa sesar aktif (Pusat Studi Gempa Nasional, 2017). Salah satu contoh gempabumi siginifikan di wilayah Lombok adalah gempabumi 5 Agustus 2019 yang memiliki dampak hingga $\mathrm{V}$ MMI atau relatif merusak di beberapa bagian Kota Mataram (Yudi, dkk., 2018).

Kondisi kegempaan ini menunjukkan pentingnya upaya mitigasi sebagai langkah pengurangan risiko bencana. Salah satu upaya untuk mitigasi adalah dengan mengetahui estimasi Peak Ground Acceleration (PGA) dari suatu kejadian gempabumi. Parameter percepatan tanah (PGA) sering digunakan untuk menggambarkan daya rusak (damage potential) suatu gempa, karena parameter percepatan ini cukup sederhana dan berhubungan langsung dengan gaya gempa efektif (Pawirodikromo, 2012). Dengan kata lain, semakin besar nilai PGA maka dampak akibat gempabumi semakin besar. Selain itu perhitungan parameter Peak Acceleration sangat diperlukan dalam pembuatan spectrum design di suatu kawasan (Taruna, dkk., 2018).

Studi mengenai database dan perkiraan percepatan tanah maksimum sudah sering dilakukan di wilayah lain, terutama pada daerah rawan bencana. Di Indonesia sendiri pengetahuan mengenai percepatan tanah maksimum diperlukan dalam pembuatan rumah tahan gempa sesuai dengan SNI 1726:2012 (Badan Standardisasi Nasional, 2012).

Ground Motion Prediction Equation (GMPE) atau persamaan atenuasi percepatan tanah merupakan suatu rumusan fisis yang digunakan untuk memperkirakan nilai PGA berdasarkan parameter sumber gempa. GMPE secara umum mempertimbangkan faktor jarak hiposenter, magnitudo gempa, dan kondisi situs tanah. GMPE biasanya dibuat secara empiris melalui regresi data pengukuran percepatan tanah yang ada.

Terdapat ratusan jenis persamaan atenuasi di seluruh dunia dengan berbagai jenis sumber gempa dengan kompleksivitas masing-masing (Douglas,
2011). Setiap persamaan juga memiliki model dan input yang berbeda. Namun sebagian besar GMPE dibuat untuk wilayah di luar Indonesia, sehingga GMPE khusus untuk wilayah Indonesia belum tersedia, termasuk untuk Kota Mataram.

Oleh karena itu diperlukan suatu prosedur untuk memilih GMPE dari wilayah lain yang paling tepat dalam memperkirakan nilai PGA di Kota Mataram. Hal utama yang diperlukan dalam pemilihan GMPE adalah kesesuaian kondisi tektonik, sehingga GMPE yang akan digunakan harus memiliki jenis sumber gempa yang sama. Prosedur dalam pemilihan dan perbandingan GMPE telah banyak dilakukan baik secara kualitatif maupun kuantitatif. Salah satu metode yang bisa digunakan dalam pemilihan GMPE adalah menggunakan aplikasi Euclidean Distance (Kale, Akkar, 2013). Kelebihan dari metode Euclidean Distance (EDR) yaitu mampu menggambarkan kesesuaian antara hasil perhitungan dan observasi dalam bentuk angka, sehingga lebih mudah untuk diperbandingkan. Selain itu metode EDR telah mempertimbangkan standar deviasi dari GMPE serta bias dari model.

Tujuan dari penelitian ini adalah untuk membandingkan nilai PGA hasil perhitungan GMPE dengan rekaman accelerograph di Kota Mataram baik menggunakan metode Euclidean Distance atau analisa residual, sehingga diperoleh persamaan percepatan yang paling sesuai untuk wilayah Mataram.

\section{METODE PENELITIAN}

Penelitian mengenai rumus percepatan tanah di Kota Mataram dilakukan pada Januari 2020. Penelitian ini diawali dengan pengumpulan data percepatan tanah maksimum akibat gempabumi di Kota Mataram. Data percepatan tanah yang digunakan diperoleh dari sensor accelerograph MAKE di Stasiun Geofisika Mataram pada periode 2016-2018 yang berjumlah 38 rekaman, dengan 30 rekaman digunakan dalam proses pemilihan, dan 8 data terakhir dalam periode pengamatan digunakan sebagai validasi. 
Selain itu digunakan parameter gempabumi yang diambil dari data BMKG (BMKG, 2019) seperti koordinat episenter, kedalaman, dan magnitudo. Data gempabumi dan lokasi sensor MAKE yang digunakan dalam penelitian ditampilkan pada Gambar 1. Dalam perhitungan juga diperlukan informasi kondisi situs tanah di Kota Mataram berdasarkan nilai kecepatan gelombang geser yang diperoleh dari penelitian Marjiyono (2016).

Parameter gempabumi digunakan sebagai input untuk menghitung nilai PGA menggunakan persamaan atenuasi (GMPE) yang telah ada. Dalam penelitian ini digunakan 4 persamaan atenuasi yang dianggap sesuai dengan kondisi kegempaan di wilayah Mataram, dan selanjutnya akan dibandingkan untuk mencari persamaan yang paling akurat. Persamaan Youngs, dkk. (1997), Kanno, dkk. (2006), Lin \& Lee, (2008) dipilih karena memiliki kesesuaian relatif baik dengan data strong motion di Indonesia (Rudyanto, 2013). Selain itu juga digunakan juga persamaan Youngs, dkk. (1997) yang telah dimodifikasi oleh (Rini, 2015). Model GMPE tersebut disajikan pada Tabel 1.

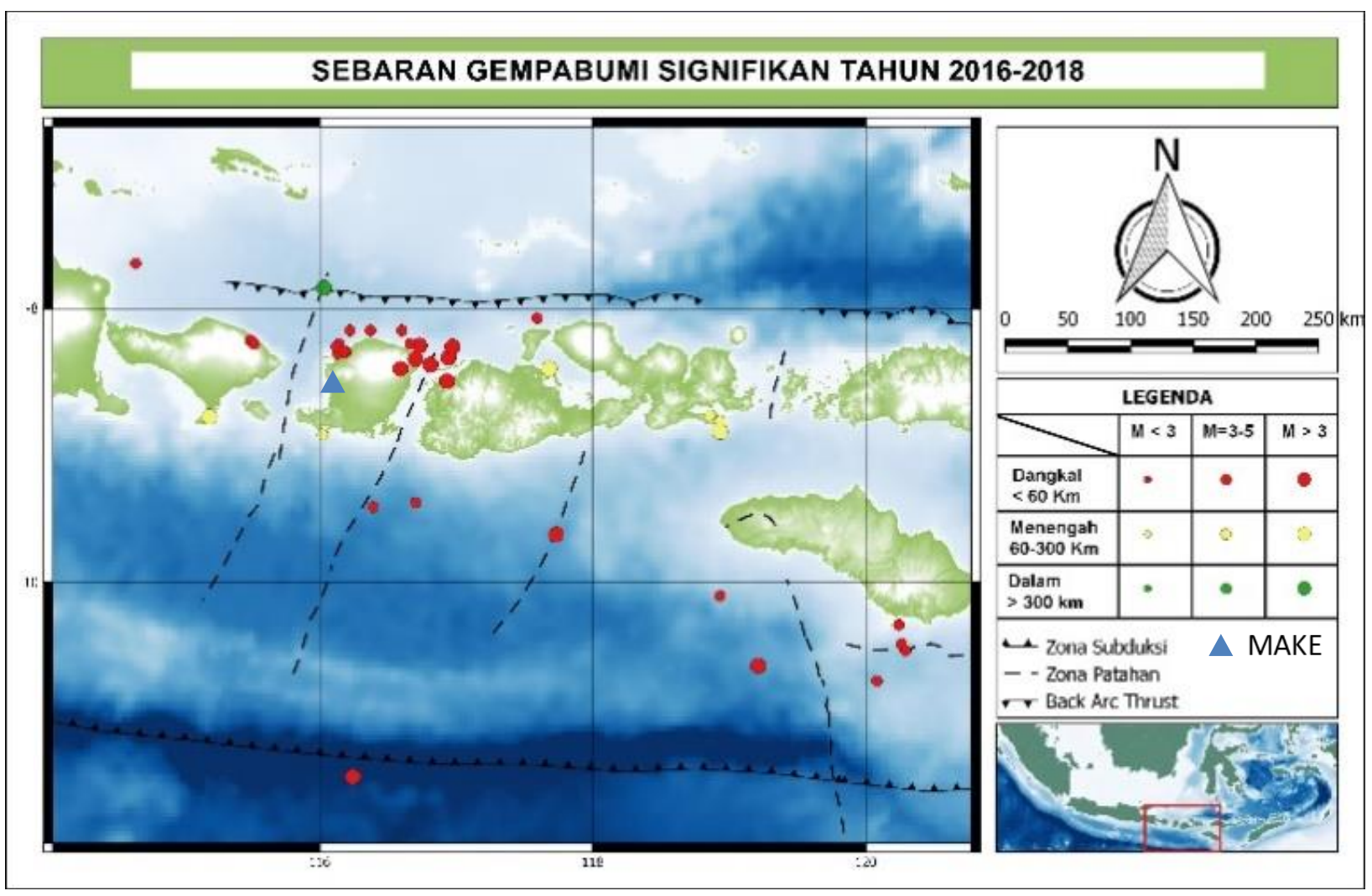

Gambar 1. Plot Data Gempabumi yang Digunakan dalam Penelitian

Tabel 1. Model GMPE yang digunakan dalam penelitian ( $Y=P G A, M w=$ magnitudo momen, $\mathrm{Zt}=$ parameter jenis gempa, $\mathrm{D}=$ kedalaman, $\mathrm{R}=$ jarak episenter, $\mathrm{Rr}=$ jarak rupture, dan $a, b, c, d, f, g, h=$ konstanta GMPE)

\begin{tabular}{|c|c|}
\hline GMPE & Model \\
\hline Youngs 97 & $\operatorname{Ln} Y=a+b \mathrm{M}_{w}+c^{*} \ln \left(R+e^{\ln (d)-f M_{w}}\right)+g Z_{t}+h \mathrm{D}$ \\
\hline Kanno 06 & $\operatorname{Ln} \mathrm{Y}=a M w-b \operatorname{Rrup}-\log \left(R r+c * 10^{d M w}\right)+f$ \\
\hline $\begin{array}{l}\text { Lin } 08 \\
\text { Youngs Modified } 15\end{array}$ & $\begin{array}{l}\operatorname{Ln} Y=a+b M w-c \ln \left(R+d e^{f M}\right)+g D+h Z_{t} \\
\operatorname{Ln} Y=a+b \mathrm{M}_{w}-c^{\star} \ln \left(R+e^{\ln \left(f M_{w}\right.}\right)+g Z_{t}+h \mathrm{D}\end{array}$ \\
\hline
\end{tabular}


Metode perbandingan antara nilai PGA hasil perhitungan (PGAcal) dengan pengukuran accelerograph (PGAobs) dilakukan secara kualitatif dan kuantitatif. Analisa kualitatif dilakukan menggunakan grafik residual dan histogram residual. Nilai residual (res) dihitung menggunakan persamaan (1).

res $=\log ($ PGAobs $)-\log (P G A c a l)$

Analisa kuantitatif dilakukan dengan menggunakan metode Euclidean Distance Ranking (EDR) (Kale \& Akkar, 2013). Metode EDR dikembangkan oleh Kale dan Akkar (2013) dalam membandingkan GMPE yang paling sesuai dengan data observasi. Metode ini dikembangkan dari konsep jarak Euclidean (DE) yang merupakan modifikasi dari konsep analisis residual. Perumusan DE ditunjukkan pada persamaan (2).

$D E=\sum_{i=1}^{N}\left(p_{i}-q_{i}\right)^{2}$

dengan $\mathrm{N}$ adalam jumlah pasangan data (p_i, q_i).

Metode EDR mengasumsikan bahwa logaritma natural dari model prediksi, khususnya DE terdistribusi normal. D dinotasikan sebagai selisih antara logaritma natural dari data observasi (a) dan data prediksi (Y) seperti rumus (3).

$D=a-Y$

Nilai diskrit dari D dinotasikan sebagai $d_{j} j$. Jumlah kemungkinan terjadinya $\mathrm{d} \_\mathrm{j}$ disebut Modified Euclidean Distance (MDE). MDE pada data diskrit dirumuskan pada persamaan (4).

$M D E_{d}=\sum_{j=1}^{n}\left|d_{j}\right| \operatorname{Pr}\left(|D|<\left|d_{j}\right|\right)$

Dalam metode ini juga dikenalkan parameter $k$ untuk mengukur tingkat penyimpangan antara data observasi dengan data prediksi. Parameter $k$ adalah perbandingan antara DEoriginal dan DEcorrected yang dirumuskan pada persamaan (5), (6), dan (7).

$k=\frac{D E_{\text {original }}}{D E_{\text {corrected }}}$

$D E_{\text {original }}^{2}=\sum_{i=1}^{N}\left(a_{i}-Y_{i}\right)^{2}$

$$
D E_{\text {corrected }}{ }^{2}=\sum_{i=1}^{N}\left(a_{i}-Y_{c, i}\right)^{2}
$$

Dengan a_i dan $Y \_i$ adalah logaritma natural dari data iobservasi dan prediksi ke-i. $\mathrm{N}$ adalah jumlah data pada database ground motion yang digunakan. Parameter Y_(c,i) adalah data estimasi ke- i yang telah dikoreksi dengan garis regresi antara logaritma data prediksi dan observasi seperti yang ditunjukkan pada persamaan (8).

$Y_{c, i}=Y_{i}-\left(Y_{f i t, i}-a_{i}\right)$

Nilai optimum dari EDR adalah 1.0 yang terjadi ketika nilai estimasi sama dengan nilai observasi yang bersesuaian. Untuk menghilangkan ketergantungan hasil EDR terhadap ukuran data maka parameter $k$ dan MDE harus dinormalisasikan dengan jumlah data $\mathrm{N}$. Perhitungan EDR secara matematis disajikan dalam persamaan (9).

$$
E D R^{2}=k \times \frac{1}{N} \times \sum_{i=1}^{N} M D E_{i}^{2}
$$

Semakin kecil nilai EDR maka data prediksi merepresentasikan dengan baik data observasi. GMPE dengan nilai EDR terkecil dianggap sebagai persamaan yang paling sesuai untuk estimasi PGA di Kota Mataram.

Sebagai validasi dilakukan perbandingan nilai PGA observasi dari 8 kejadian gempa terakhir pada periode data dengan nilai PGA hasil perhitungan persamaan terpilih. Perbandingan dilakukan dengan membuat kurva atenuasi persamaan terpilih dengan data yang divalidasi.bagaimana data dikumpulkan, sumber data dan cara analisis data

\section{HASIL DAN PEMBAHASAN Database Ground Motion}

Dalam pembuatan database ground motion, selain parameter jarak episenter, kedalaman, dan magnitudo, diperlukan juga informasi jenis gempabumi. Sebaran data gempa menurut magnitudo dan kedalaman ditunjukkan pada Gambar 2. Berdasarkan Gambar 2 terlihat bahwa sebagian besar kejadian gempa yang digunakan memiliki magnitudo 3,0-5,5 
serta berjarak antara $25-200 \mathrm{~km}$, hanya

$M>5,5$ dan jarak $>200 \mathrm{~km}$.

sebagian data yang memiliki magnitudo

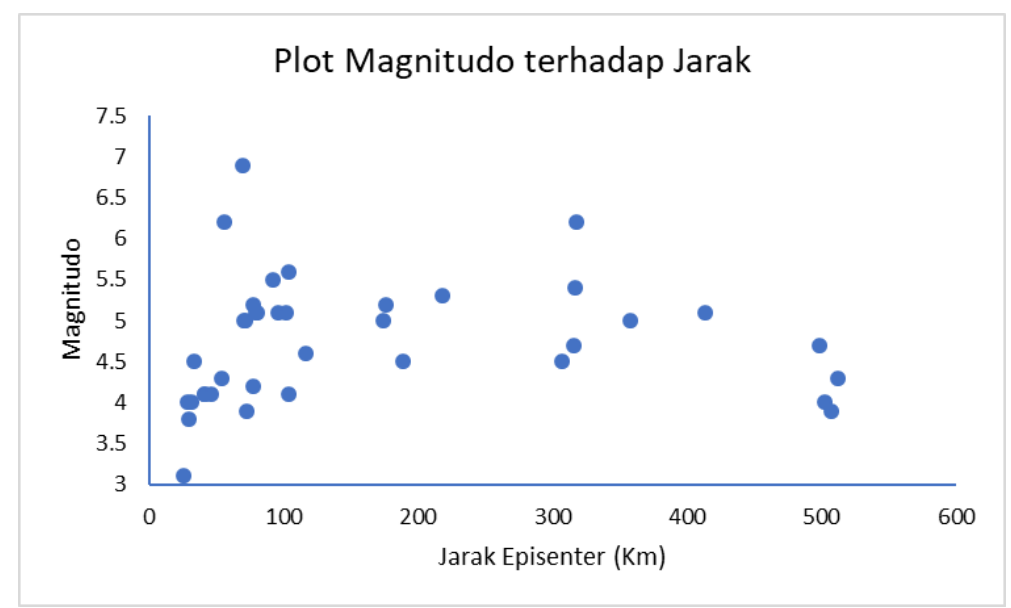

Gambar 2. Plot Magnitudo Terhadap Jarak Episenter Dari Gempabumi Yang Digunakan Dalam Penelitian

Selain itu, analisa Persebaran data nilai $P G A$ terhadap jarak juga dilakukan untuk mengetahui kualitas data $P G A$ hasil observasi. Plot nilai PGA observasi terhadap jarak ditampilkan pada Gambar 3. Gambar 3 menunjukkan bahwa nilai $P G A$ memiliki tren menurun seiring dengan bertambahnya jarak episenter. Nilai $P G A$ observasi berada pada rentang sekitar 0,1-95 gal. Selain itu dapat dilihat terdapat beberapa data yang relatif jauh dari tren atenuasi, terutama pada rentang magnitudo 3-3,9 dan 5-5,9, hal ini menunjukkan bahwa kualitas data pada rentang magnitudo tersebut kurang baik.
Dalam penelitian ini jenis gempabumi ditentukan berdasarkan lokasi titik gempabumi terhadap zona subduksi, back arc thrust, dan patahan. Jenis gempabumi terbagi atas interface, intraslab, dan crustal. Analisa terhadap posisi hiposenter dan kedalaman gempa terhadap zona subduksi, back arc thrust, serta patahan menunjukkan bahwa 23 kejadian gempa termasuk dalam gempa interface atau berada di zona megathrust, dan 7 kejadian gempa merupakan gempa crustal yang berada di sekitar daerah patahan, sedangkan 8 lainya berada di dalam zona intraslab.

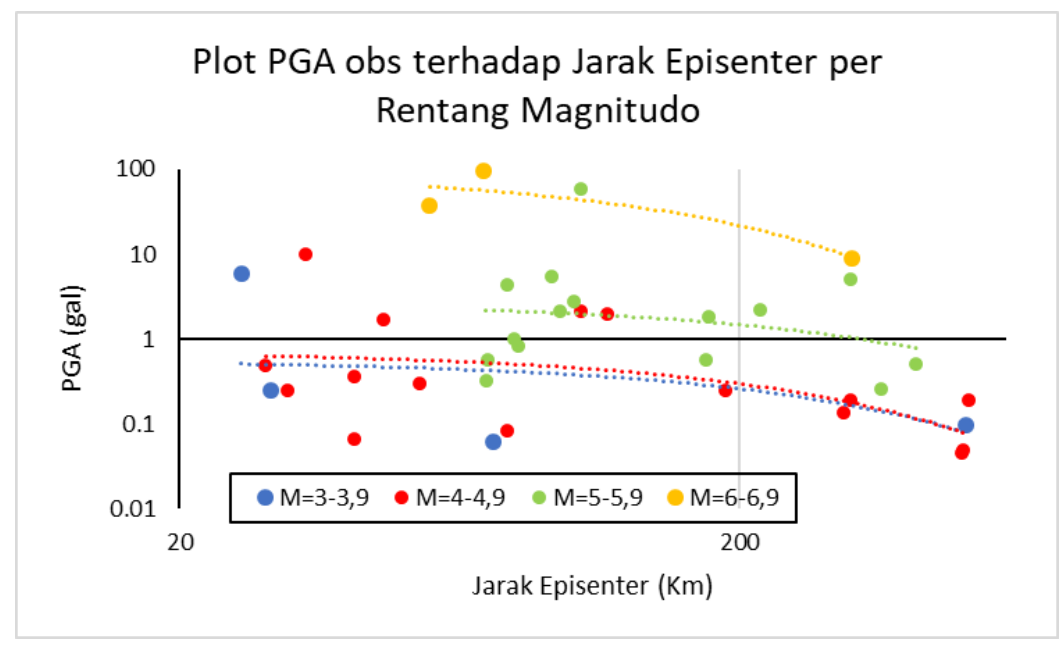

Gambar 3. Plot PGA Observasi Terhadap Jarak Episenter Per Rentang Magnitudo Dari Gempabumi Yang Digunakan Dalam Penelitian 


\section{Perhitungan PGA dengan Rumus Empiris (GMPE)}

GMPE digunakan untuk menghitung nilai $P G A$ secara empiris berdasarkan input parameter gempa. Dalam penelitian ini dilakukan perhitungan nilai $P G A$ berdasarkan persamaan Youngs 97, Kanno 06, Lin 08, dan Youngs Modified 15. Gambar 4 menunjukkan kurva atenuasi dari setiap persamaan yang digunakan untuk $\mathrm{Mw}=5,0$ dan kedalaman $30 \mathrm{Km}$ pada zona interface. Kurva atenuasi Youngs 97 memiliki nilai relatif lebih besar dibandingkan persamaan lain, terutama pada jarak $<100 \mathrm{~km}$. Persamaan Lin 08 memiliki nilai $P G A$ cenderung lebih besar pada jarak $>100 \mathrm{~km}$ dibandingkan persamaan lainya. Sedangkan Kanno 06 memiliki kurva atenuasi paling rendah dibanding GMPE lain.

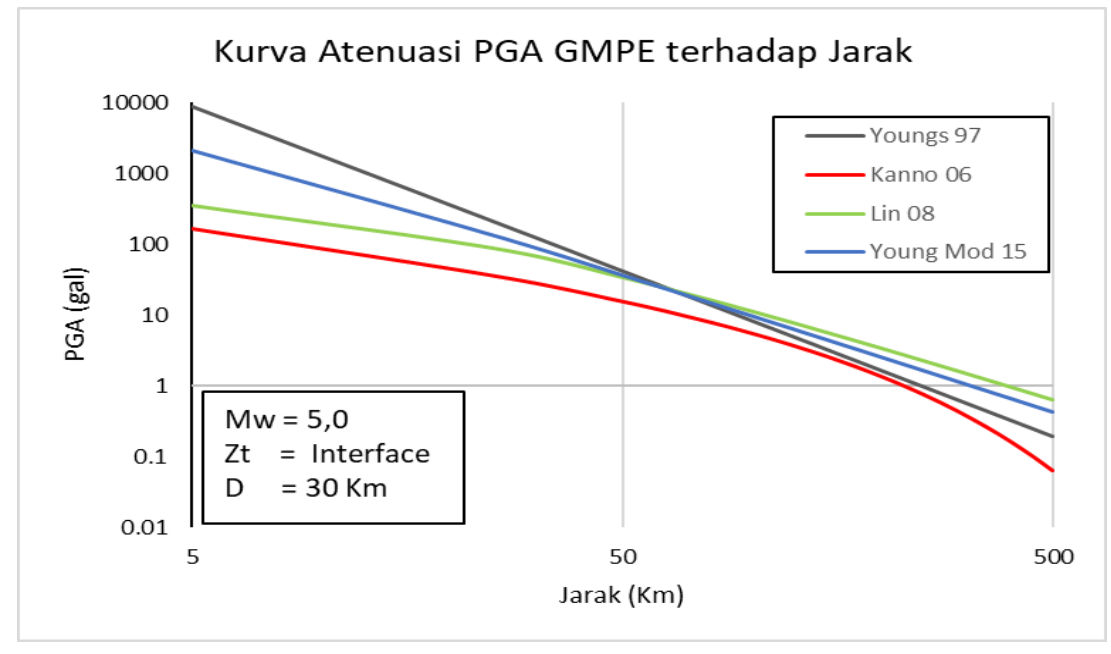

Gambar 4. Plot PGA terhadap Jarak dari Hasil Perhitungan GMPE

\section{Residual PGA Empiris dengan PGA Observasi}

Hasil perhitungan PGA dari GMPE selanjutnya akan dibandingkan dengan data PGA observasi dari 30 rekaman accelerograph di sensor MAKE. Grafik perbandingan residual dari masingmasing GMPE ditampilkan pada Gambar 5. Secara kualitatif grafik residual menunjukkan bahwa GMPE Kanno 06 memiliki sebaran residual relatif kecil dibandingkan persamaan lainya.

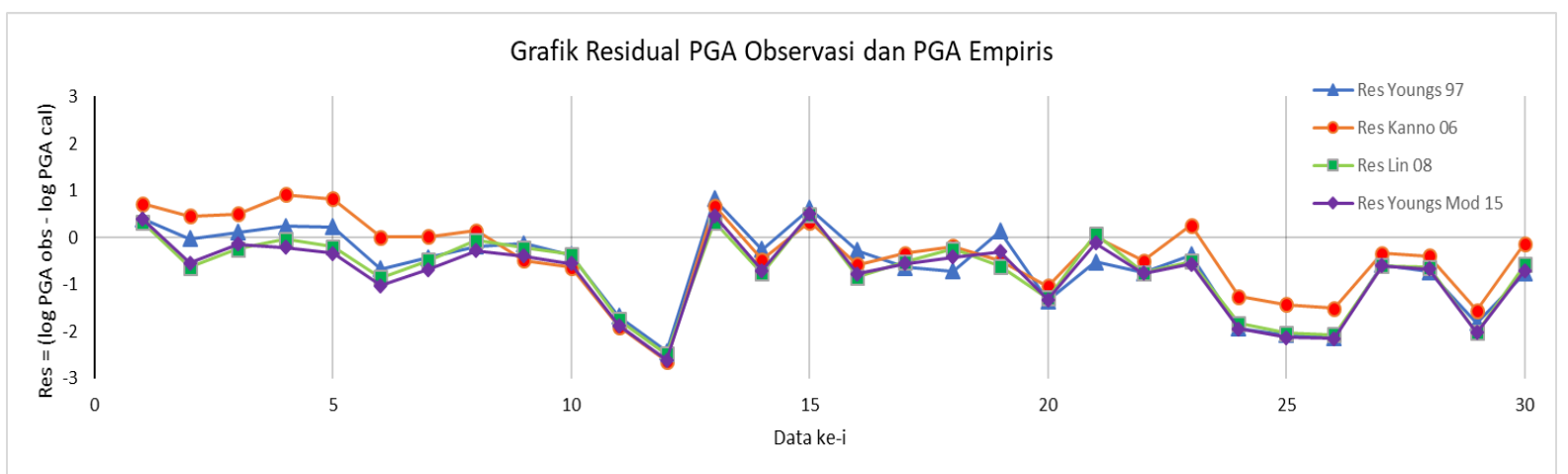

Gambar 5. Plot Residual PGA dari Hasil Perhitungan GMPE dan PGA Observasi

Gambar 5 menggambarkan bahwa pada beberapa titik nilai residual relatif besar. Hal ini bisa saja diakibatkan oleh kualitas rekaman yang kurang baik pada data tersebut seperti yang telah dijelaskan dalam pembahasan sebelumnya. Penyimpangan semacam ini biasa disebut dengan outlier yang perlu dipertimbangkan dalam proses regresi (Grandis, 2009). 
Kualitas GMPE juga bisa diketahui melalui histogram distribusi residual masing-masing persamaan. GMPE yang baik memiliki distribusi residual yang didominasi residual dengan nilai mendekati nol. Selain itu, histogram yang baik akan mengikuti bell shaped curve. Histogram resiudal dari masing-masing persamaan ditampilkan pada Gambar 6.

Gambar 6 menunjukkan bahwa histogram semua GMPE memiliki distribusi residual yang cukup baik, yaitu frekuensi terbanyak terdapat pada residual mendekati nol. Namun, secara umum distribusi residual belum mendekati bentuk bell shaped curve, sehingga nilai residual lebih dari $\pm 0,5$ relatif banyak. Secara kualitatif juga terlihat bahwa persamaan Kanno 06 memiliki histogram relatif baik dibanding persamaan lainya, terutama pada nilai residual $<-0,5$.

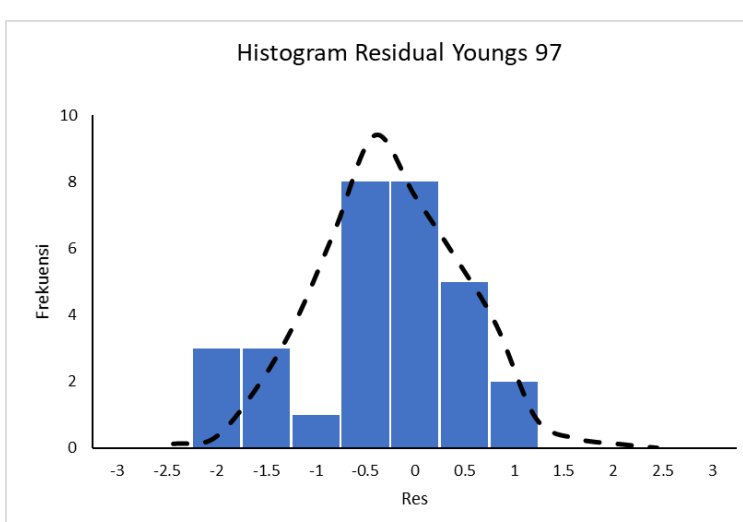

(a)

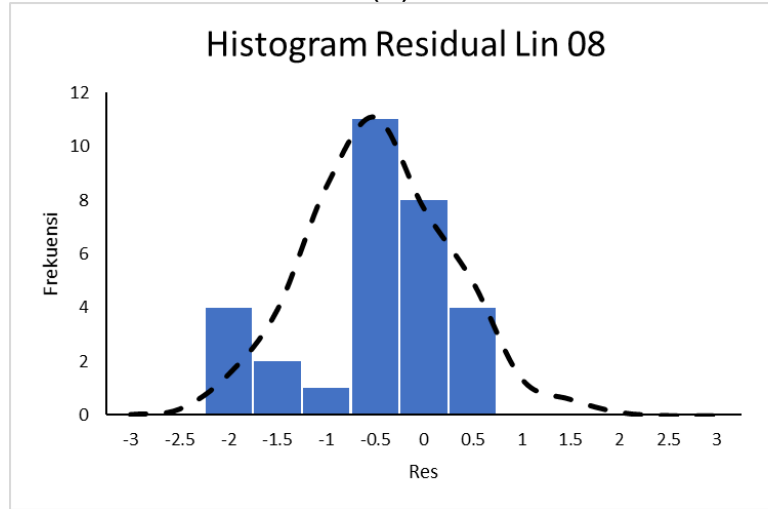

(c)

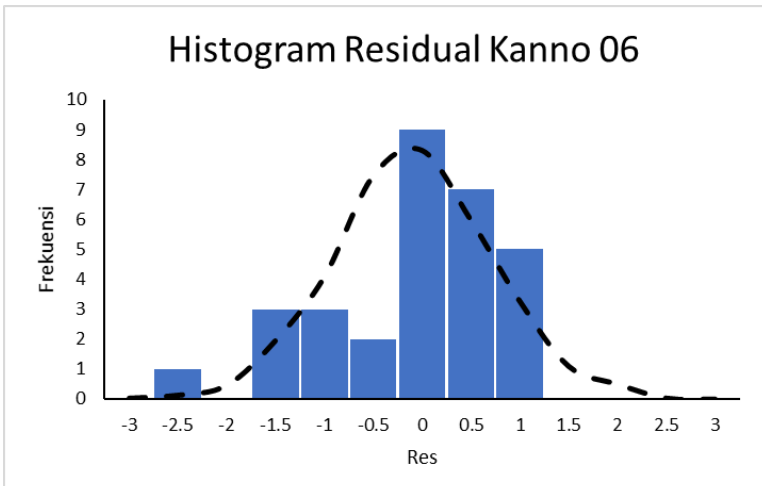

(b)

Histogram Residual Youngs Modified 15

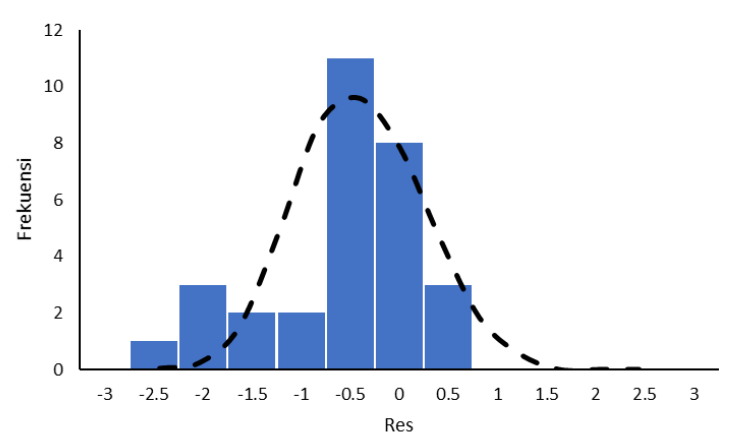

(d)

Gambar 6. Histogram Residual Persamaan a) Youngs 97, b) Kanno 06, c) Lin 08, dan d) Youngs Modified 15

\section{Pemilihan GMPE Berdasarkan Metode EDR}

Metode kuantitatif yang digunakan dalam pemilihan GMPE yang sesuai adalah dengan menggunakan metode Euclidean Distance Ranking. Hasil perhitungan metode EDR untuk masingmasing GMPE ditampilkan pada Tabel 2. Semakin kecil nilai $E D R$ maka kesesuaian antara nilai observasi dan empiris semakin baik. Pada Tabel 2 terlihat bahwa persamaan Youngs 97 memiliki nilai EDR paling besar, karena persamaan Youngs 97 dibuat menggunakan data gempa subduksi di seluruh dunia. Hasil dari metode EDR juga didukung dengan analisa kualitatif melalui grafik dan histogram residual $P G A$. 
Tabel 2. Hasil Perhitungan Metode EDR

\begin{tabular}{cccc}
\hline Model GMPE & MDE & k & EDR \\
\hline Youngs 97 & 64,63 & 1,22 & 78,99 \\
Kanno 06 & 13,19 & 1,05 & 13,89 \\
Lin 08 & 18,85 & 1,12 & 21,07 \\
Youngs Mod. 15 & 25,51 & 1,09 & 27,73 \\
\hline
\end{tabular}

Berdasarkan Tabel 2 nilai EDR terkecil terdapat pada persamaan Kanno 06 , yaitu 13,89 . Hasil tersebut juga sesuai dengan grafik dan histogram residual yang menunjukkan bahwa tren residual Kanno 06 memiliki nilai paling kecil dibandingkan persamaan lain. Hal ini disebabkan oleh faktor kemiripan kondisi tektonik antara data yang digunakan dalam pembuatan persamaan Kanno 06 dengan Pulau Lombok. Persamaan Kanno 06 dikembangkan untuk wilayah Jepang

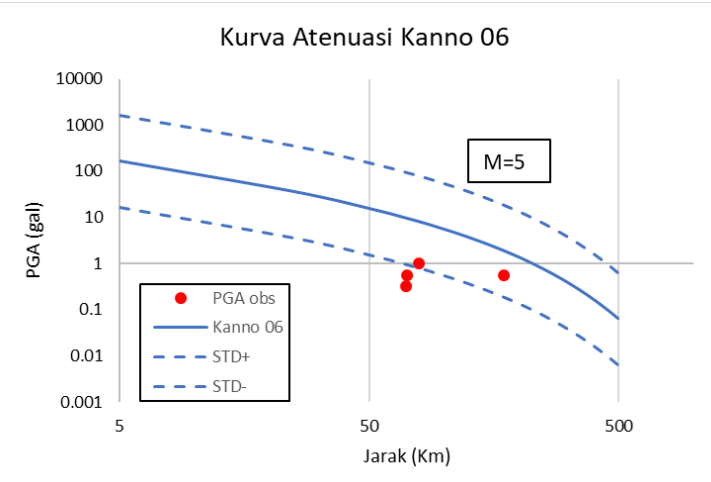

(a) yang memiliki sumber gempa subduksi dan fault.

Namun, hasil perhitungan EDR juga menunjukkan bahwa kualitas dari semua persamaan belum terlalu baik. Hal ini terlihat dari nilai EDR setiap persamaan $>10$, sementara nilai optimal EDR adalah 1. Hasil tersebut menunjukkan bahwa masih ada beberapa pasangan data yang memiliki nilai residual relatif besar.

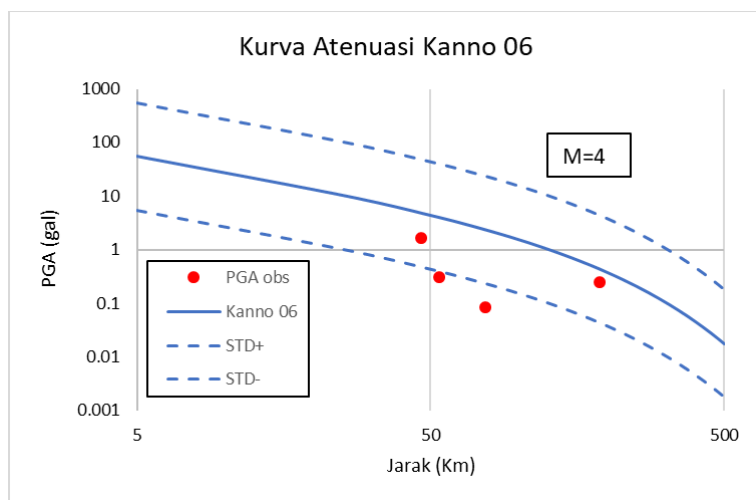

(b)

Gambar 7. Kurva Atenuasi Kanno 06 dan $P G A$ Observasi untuk a) $M=5$ dan b) $M=4$

Kondisi tersebut juga terlihat pada hasil validasi persamaan Kanno 06 dengan data rekaman 8 kejadian gempabumi terakhir di periode data seperti yang ditampilkan pada Gambar 7 . Kurva atenuasi pada Gambar 7 telah dinormalisasikan ke dalam 2 kelompok magnitudo, yaitu $M=5$ dan $M=4$. Gambar 7 menunjukkan bahwa kurva atenuasi Kanno 06 mampu memprediksi beberapa data observasi dengan baik, namun juga terdapat beberapa data observasi yang berada di luar garis deviasi. Hal ini menunjukkan bahwa secara umum persamaan Kanno 06 memiliki kemampuan relatif baik dalam mengestimasi nilai $P G A$ dibanding persamaan lainya, namun masih memiliki deviasi cukup besar dan akurasi kurang baik untuk memprediksi nilai $P G A$.

\section{SIMPULAN DAN SARAN}

Aplikasi metode Euclidean Distance dalam menentukan Rumus Percepatan Tanah akibat Gempabumi di Kota Mataram menunjukkan bahwa persamaan (Kanno, dkk., (2006) memiliki tingkat realibilitas terbaik dibandingkan persamaan lain.

Metode EDR mampu menentukan dengan baik kesesuaian antara data hasil perhitungan dengan data observasi. Hal ini dapat terlihat dari hasil metode EDR yang relatif sama dengan hasil plot residual serta histogram distribusi residual dari setiap persamaan. persamaan 
Namun, metode EDR juga menunjukkan bahwa persamaan terpilih masih memiliki penyimpangan relatif besar. Hal itu dapat disebabkan oleh beberapa faktor, antara lain basis data atau wilayah persamaan atenuasi, jenis jarak gempa yang digunakan serta perlunya proses relokasi gempabumi.

Oleh karena itu disarankan dalam penelitian selanjutnya diawali oleh proses relokasi posisi gempa dan memiliki data parameter gempa yang lebih lengkap. Selain itu diharapkan agar dapat dibuat suatu persamaan atenuasi khusus untuk wilayah Indonesia, khususnya wilayah Mataram.

\section{UCAPAN TERIMA KASIH}

Terima kasih kami sampaikan kepada Badan Meteorologi, Klimatologi, dan Geofisika, khususnya Stasiun Geofisika Mataram yang telah memberikan banyak dukungan dalam penelitian ini serta penyediaan data dan perangkat lunak dalam proses pengolahan.

\section{REFERENSI}

Badan Standardisasi Nasional. 2012. SNI 1726:2012 Tata Cara Perencanaan Ketahanan Gempa Untuk Struktur Bangunan Gedung dan Non Gedung. Jakarta: Departemen Pekerjaan Umum, diambil dari www.bsn.go.id

BMKG. 2019. BMKG Data Repository. Diambil dari http://repogempa.bmkg.go.id/query.p hp, diakses 10 Agustus 2019

Douglas, J. 2011. Ground-motion Prediction Equations 1964-2010 PEER Report 2011/102. Berkeley: Pacific Earthquake Engineering Research Center College of Engineering University of California.

Grandis, H. (2009). Pengantar Pemodelan Inversi Geofisika. Jakarta: Badan Meteorologi Klimatologi dan Geofisika

Kale, Ö., \& Akkar, S. 2013. A new procedure for selecting and ranking ground-motion prediction equations (GMPEs): The Euclidean distancebased ranking (EDR) method. Bulletin of the Seismological Society of America, 103(2 A), 1069-1084.
Kanno, T. 2006. A New Attenuation Relation for Strong Ground Motion in Japan Based on Recorded Data. Bulletin of the Seismological Society of America, 96(3), 879-897.

Lin, P.-S., \& Lee, C.T. 2008. GroundMotion Attenuation Relationships for Subduction-Zone Earthquakes in Northeastern Taiwan. Bulletin of the Seismological Society of America, 98(1), 220-240.

Mahendra Taruna, R., Haris Banyunegoro, V., \& Daniarsyad, G. 2018. Peak ground acceleration at surface for Mataram city with a return period of 2500 years using probabilistic method. MATEC Web of Conferences, 195.

Marjiyono. 2016. Potensi Penguatan Gelombang Gempabumi oleh Sedimen Permukaan Kota Mataram, Nusa Tenggara Barat. Jurnal Lingkungan dan Bencana Geologi, 7(3), 135-144.

Pawirodikromo, W. 2012. Seismologi Teknik \& Rekayasa Kegempaan.

Pusat Studi Gempa Nasional. 2017. Peta sumber dan bahaya gempa Indonesia tahun 2017.

Rini, V. S. 2015. Kajian Awal Persamaan Prediksi Percepatan Tanah di Zona Subduksi Wilayah Bali dan Sekitarnya. Sekolah Tinggi Meteorologi Klimatologi dan Geofisika.

Rudyanto, A. 2013. Development of Strong-motion Database For The Sumatra-Java Region. Australian National University.

Sari R, A. Wirma. 2013. Analisis Rekahan Gempa Bumi Dan Gempa Bumi Susulan Dengan Menggunakan Metode Omori . Jurnal Sains dan Pendidikan Fisika. Jilid 8, Nomor 3, Desember 2012.

Taruna, R. M., \& Banyunegoro, V. H. 2018. Earthquake Relocation Using Double Difference Method for 2D Modelling of Subducting Slab and Back Arc Thrust in West Nusa Tenggara. Jurnal Penelitian Fisika dan Aplikasinya (JPFA), 8(2), 132143 
Youngs, R. R., Chiou, S. J., Silva, W. J., \& Humphrey, J. R. 1997. Strong Ground Motion Attenuation Relationships for Subduction Zone Earthquakes. Seismological Research Letters, 68(1), 58-73.

Yudi, A., Santoso, E., Kaluku, A., \& Artadi Pria Sakti, Sigit Pramono, D. P. 2018. Ulasan Guncangan Tanah Akibat Gempa Lombok Timur 05 Agustus 2018. In Badan Metalurgi, Klimatologi dan Geofisika. Diambil dari https://prosesweb.bmkg.go.id/wpcontent/uploads/Ulasan-GuncanganGempa-Lombok-Timur-29072018.pdf 